\begin{tabular}{|c|c|c|c|}
\hline International Journal of Herbal Medicine & I \\
\hline \hline Available online at www.florajournal.com & $\begin{array}{c}\text { Intruatuual } \\
\text { Journal } \\
\text { of } \\
\text { Herbal } \\
\text { Medicine }\end{array}$ \\
\hline \hline
\end{tabular}

E-ISSN: 2321-2187

P-ISSN: 2394-0514

www.florajournal.com

IJHM 2021; 9(5): 55-61

Received: 17-09-2021

Accepted: 20-10-2021

Shreyasi Halder

Senior Research Fellow,

Nutrition Research Laboratory,

Department of Home Science,

University of Calcutta, Kolkata,

West Bengal, India

Kazi Layla Khaled

Associate Professor,

Nutrition Research Laboratory, Department of Home Science,

University of Calcutta, Kolkata,

West Bengal, India
Corresponding Author: Shreyasi Halder

Senior Research Fellow,

Nutrition Research Laboratory, Department of Home Science,

University of Calcutta, Kolkata,

West Bengal, India

\section{Anti-nutritional profiling from the edible flowers of Allium cepa, Cucurbita maxima and Carica papaya and its comparison with other commonly consumed flowers}

\author{
Shreyasi Halder and Kazi Layla Khaled
}

DOI: https://doi.org/10.22271/flora.2021.v9.i6a.784

\begin{abstract}
Antinutrients, also known as 'secondary metabolites' in plants are highly biologically active chemical compounds synthesized in natural food or feedstuffs by the normal metabolism of species which prevents optimal exploitation of the nutrients present in a food. Consumption of edible flowers has increased over the years as the phytochemicals in them have been found to possess numerous health benefits. However, many edible flowers remain unexplored and underutilized. The present study quantifies and compares the anti-nutritional (tannins, phytates, oxalates, alkaloids and saponin) content of the three edible flowers of Allium cepa, Carica papaya and Cucurbita maxima with four other commonly consumed edible flowers.It was found that the three flowers have relatively a lower concentration of all the measured antinutrients when compared with its respective bulb/fruit and stalk/leaf. Also when compared to the edible flowers of Moringa oleifera, Musa paradisiaca, Musa acuminata and Woodfordia fruticosa (L.) Kurz, the test flowers have a much lower antinutritional content. This relatively small presence of antinutrients in the three test flowers makes them suitable for safe consumption.
\end{abstract}

Keywords: Edible flowers, anti-nutrients, phytochemicals, Allium cepa, Carica papaya, Cucurbita maxima

\section{Introduction}

Edible flowers are a rich source of thousands of various nutrients and are consumed by rural people frequently. However, the key problem related to the nutritional exploitation of these kinds of edible plants is the presence of antinutritional factors. Antinutrients are found in their highest concentrations in grains, beans, legumes and nuts, but can also be found in leaves, roots and fruits or even flowers of certain varieties of plants. Plants evolved antinutrients to protect themselves and to prevent them from being eaten ${ }^{[1]}$. Antinutrients are natural or synthetic compounds that interfere with the absorption of nutrients present in the food. Although they are not necessarily toxic plant compounds but they decrease the nutritional value of a plant food, usually by making an essential nutrient unavailable or indigestible when consumed by humans or animals [2]. Some vitamins in food may be destroyed by antinutritional substances. For example, aflatoxin in groundnut has been found to cause severe liver damage if consumed in excess ${ }^{[3]}$. Like aflatoxin several other anti-nutritional factors must be inactivated or removed if values of food substances are to be fully maintained. This study is designed to quantify the anti-nutritional factors present in the three edible flowers (per $100 \mathrm{gm}$ fresh flowers) of Allium cepa (onion) flower, Carica papaya (papaya) flower and Cucurbita maxima (pumpkin) flower.

Allium cepa: inflorescence is a spherical umbel, 2-8 cm in diameter with 50-2000 flowers; flowers sub campanulate to urceolate; tepals 6 in 2 whorls, ovate to oblong, 3-5 mm long, greenish-white to purple. Onion cultivars are about $89 \%$ water, $9 \%$ carbohydrates, $1 \%$ protein and have energy value of $166 \mathrm{KJ}^{[4]}$.

Carica papaya: flowers are 5-parted and highly dimorphic, the male flowers with the stamens fused to the petals. The female flowers have a superior ovary and five contorted petals loosely connected at the base. The flowers are fragranced, trumpet-shaped and yellowish-whitish in colour, blooming throughout the year, The papaya flower tastes bitter, is rich in vitamins A, C and $\mathrm{E}$ and is also a good source of dietary fibre. A study in Philippines confirmed the male papaya flower as a functional ingredient for herbal tea production primarily owing to its appealing aroma ${ }^{[5]}$. 
Traditionally, the male flowers are cooked and used as a green vegetable. In Java, a sweetmeat is made from the flowers.

Cucurbita maxima: a member of the Cucurbitaceae family is one of the most common vegetables consumed worldwide. From ancient days the flowers of pumpkin are consumed locally as vegetable in Mexico and India.

Male flowers are borne straight off the vine while females have a small fruit swelling at the base near the stem. Pumpkin flowers are pentamerous, axillary, solitary, bright yellow or orangey yellow coloured. Pumpkin flowers consist of $9.2 \mathrm{mg}$ of vitamin $\mathrm{C}$ and huge amount of folic acid ${ }^{[6]}$. The activities of the glyoxylate cycle, isocitrate lyase and malate synthase, were detectable in petals of pumpkin flower ${ }^{[7]}$.

This paper aims to:

- To determine and quantify the anti-nutritional factors in Allium cepa, Carica papaya and Cucurbita maxima flowers.

- To compare the identified anti-nutrient content of Allium cepa, Carica papaya and Cucurbita maxima flowers with their bulb/fruit and stalk/leaf.

- To compare the anti-nutrients of the test flowers with four other common edible flowers namely, Moringa oleifera, Musa paradisiaca, Musa acuminata and Woodfordia fruticosa (L.) Kurz.

Anti-nutrients are one of the key factors which reduce the bioavailability of various components of the cereals and legumes. These compounds are of natural or synthetic origin, interfere with the absorption of nutrients and can be responsible for micronutrient malnutrition and mineral deficiencies. Major anti-nutritional factors found in edible crops include saponins, tannins, phytic acid, alkaloids, lectins, protease inhibitors etc. However some antinutrients may exert beneficial health effects at low concentrations. For example, when used at low levels, phytate, lectins, tannins, amylase inhibitors and saponins may reduce the blood glucose and insulin responses to starchy foods and triglycerides.

\section{Materials and Methods}

\subsection{Sample Collection and Identification}

Whole flower samples were collected from local markets of Kolkata and Baruipur. The flower samples were taxonomically identified, authenticated and the voucher specimen numbers were assigned by Central National Herbarium, Botanical Survey of India.

\subsection{Preparationof flower extract}

Flower samples were separated and cleaned thoroughly. Sample paste was made by grinding in a mixer grinder and freeze dried (by using Laboratory Freeze Dryer, ModelDPRG - 01). The methanolic extract of the flowers were prepared by adding $1 \mathrm{~g}$ of each freeze-dried sample powder to $100 \mathrm{ml}$ of methanol. The infusions were stirred on the magnetic stirrer at room temperature for $5 \mathrm{~h}$ and then centrifuged at $6000 \mathrm{rpm}$ at $4{ }^{\circ} \mathrm{C}$ for $10 \mathrm{~min}$ (Eppendorf, centrifuge $5430 \mathrm{R})$. The supernatants were stored at $-4{ }^{\circ} \mathrm{C}$ for further experiments.

\subsection{Anti-nutritional factor determination}

The extract was tested for the presence of bioactive compounds by using the following standard methods:

\subsubsection{Estimation of tannin by spectrophotometric method [8]}

Tannin contents of the flower samples were measured by Folin-Denis method. Accurately Weighed $0.5 \mathrm{~g}$ of the powdered sample was transferred to a $250 \mathrm{~mL}$ conical flask and $75 \mathrm{~mL}$ of water was added. The flask was gently heated and boiled for $30 \mathrm{~min}$, centrifuged at 2,000rpm for $20 \mathrm{~min}$ and the supernatant collected in $100 \mathrm{~mL}$ volumetric flask and the volume made up. Next, $1 \mathrm{~mL}$ of the sample extract was transferred to a $100 \mathrm{~mL}$ volumetric flask containing $75 \mathrm{~mL}$ water. $5 \mathrm{~mL}$ of Folin-Denis reagent, $10 \mathrm{~mL}$ of sodium carbonate solution were mixed and diluted to $100 \mathrm{~mL}$ with water. Absorbance read at $700 \mathrm{~nm}$ after $30 \mathrm{~min}$ with UVVisible spectrophotometer. The tannin concentration was determined by the standard graph of tannic acid solution.

$$
\% \text { Tannin }(\mathrm{mg} / 100 \mathrm{~g})=\frac{\mathrm{An} \times \mathrm{C} \times \mathrm{Df}}{\mathrm{As} \times \mathrm{W} \times 100}
$$

Where: An = absorbance of test sample, As = absorbance of standard tannic acid, $\mathrm{C}=$ concentration of standard tannic acid $(\mathrm{mg} / \mathrm{ml}), \mathrm{Df}=$ dilution factor, $\mathrm{W}=$ weight of test sample (mg).

\subsubsection{Estimation of phytate by titrimetric methods [9]}

About $2.0 \mathrm{~g}$ of the sample was weighed into a $250 \mathrm{~mL}$ conical flask. $100 \mathrm{~mL} 2 \%$ concentrated $\mathrm{HCl}$ was used to soak sample for $3 \mathrm{~h}$ and then filtered with a Whatman No. 1 filter paper. $50 \mathrm{ml}$ of the filtrate and $10 \mathrm{ml}$ of distilled water were mixed together and titrated against standard $\mathrm{FeCl} 3$ solution containing $0.00195 \mathrm{~g}$ Iron $/ \mathrm{ml}$ until a brownish yellow colour persisted for five min. The percentage phytic acid was calculated thus:

$\%$ Phytic acid $=\mathrm{y} \times 1.19 \times 100$

Where, $\mathrm{y}=$ titre value $\times 0.00195 \mathrm{~g}$

2.3.3 Determination of oxalate by titrimetric methods ${ }^{[10]}$ $1 \mathrm{~g}$ of sample was weighed into $100 \mathrm{ml}$ conical flask. $75 \mathrm{ml}$ $3 \mathrm{MH}_{2} \mathrm{SO}_{4}$ was added and stirred for $1 \mathrm{hr}$ with a magnetic stirrer. This was filtered using a Whatman No 1 filter paper. $25 \mathrm{ml}$ of the filtrate was then taken and titrated while hot against $0.05 \mathrm{M} \mathrm{KMnO}_{4}$ solution until a faint pink colour persisted for at least $30 \mathrm{~s}$.

The oxalate content was then calculated by taking $1 \mathrm{ml}$ of $0.05 \mathrm{~m} \mathrm{KMnO}_{4}$ as equivalent to $2.2 \mathrm{mg}$ oxalate.

\subsubsection{Determination of total alkaloids by titrimetric methods ${ }^{[11]}$}

$5 \mathrm{gm}$ of powdered sample was taken into $20 \mathrm{ml}$ of n-butanol and vigorously stirred. The content was transferred into a reagent bottle and kept overnight at room temperature. Centrifuged at $6000 \mathrm{rpm}$ for $10 \mathrm{~min}$ and the supernatant was made up to $50 \mathrm{ml}$ with n-butanol. $10 \mathrm{ml}$ of the supernatant and $10 \mathrm{ml}$ of $0.1(\mathrm{~N}) . \mathrm{HCl}$ was taken into a $100 \mathrm{ml}$ separating funnel and shaken thoroughly for 2-3 min. The lower layer of alkaloids neutralized $10 \mathrm{ml} \mathrm{HCL}$ portion was collected in a beaker and 2-3 drops methyl red was added to it, that turns the solution into slightly reddish colour. The contents of beaker were titrated against $0.1(\mathrm{~N}) \mathrm{NaOH}$, till colour change changed from red to pale yellow. The neutralization point was determined. Same procedure was repeated triplicate.

The total amount of alkaloids was calculated by considering, $1 \mathrm{ml} 0.1 \mathrm{~N} \mathrm{HCl} \equiv 0.0162$ g alkaloid. 
2.3.5 Determination of total saponin content by spectrophotometric method ${ }^{[12]}$

To $2 \mathrm{~g}$ of the sample extract $100 \mathrm{~mL}$ of $20 \%$ aqueous ethanol was added and incubated in a water bath at a temperature of $55{ }^{\circ} \mathrm{C}$ for $4 \mathrm{~h}$ with continuous stirring. The mixture was filtered and re-extracted with $200 \mathrm{~mL}$ of $20 \%$ ethanol and the combined extract was reduced to 40 milk. The concentrated filtrate was transferred into a $250 \mathrm{~mL}$ separating funnel and $20 \mathrm{~mL}$ of diethyl ether was added to it and shaken vigorously. The aqueous layer was collected and extracted three times with $30 \mathrm{~mL}$ of $\mathrm{n}$-butanol. The extract was washed three times with $10 \mathrm{~mL}$ of $5 \% \mathrm{NaCl}$ and heated to evaporate the n-butanol and the samples were dried in the oven at $40{ }^{\circ} \mathrm{C}$ to a constant weight. Vanillin-acetic acid $(0.2 \mathrm{~mL}, 5 \% \mathrm{w} / \mathrm{v})$ and $0.8 \mathrm{~mL}$ of perchloric acid were added to 50 all of the n-butanol extract and heated to $70{ }^{\circ} \mathrm{C}$ for $15 \mathrm{~min}$. The mixture was cooled on an ice bath for $1 \mathrm{~min}$ and $5.0 \mathrm{~mL}$ of glacial acetic acid was added to it. Absorbance read at a wavelength of $550 \mathrm{~nm}$ with UVVisible spectrophotometer.

\section{Results and Discussion 3.1 Anti-nutritional Characterization}

Table 1: Quantitative analysis of Antinutritional content from Allium cepa, Carica papaya and Cucurbita maxima flowers (per 100g weight)

\begin{tabular}{|c|c|c|c|}
\hline \multirow{2}{*}{ Antinutritional factors $(\mathbf{m g} / \mathbf{1 0 0 g m})$} & \multicolumn{3}{|c|}{ Flower samples } \\
\cline { 2 - 4 } & Allium cepa & Carica papaya & Cucurbita maxima \\
\hline Tannins & $1.72 \pm 0.35$ & $0.44 \pm 0.36$ & $2.16 \pm 0.17$ \\
\hline Phytates & $3.06 \pm 0.03$ & $6.58 \pm 0.05$ & $5.07 \pm 0.10$ \\
\hline Oxalates & $1.51 \pm 0.16$ & $3.18 \pm 0.18$ & $0.2 \pm 0.19$ \\
\hline Alkaloids & $0.88 \pm 0.43$ & $0.18 \pm 0.02$ & $0.35 \pm 0.55$ \\
\hline Saponins & $850 \pm 10$ & $230 \pm 20$ & $50 \pm 30$ \\
\hline
\end{tabular}

Results presented are mean $\pm \operatorname{SEM}(\mathrm{n}=3)$

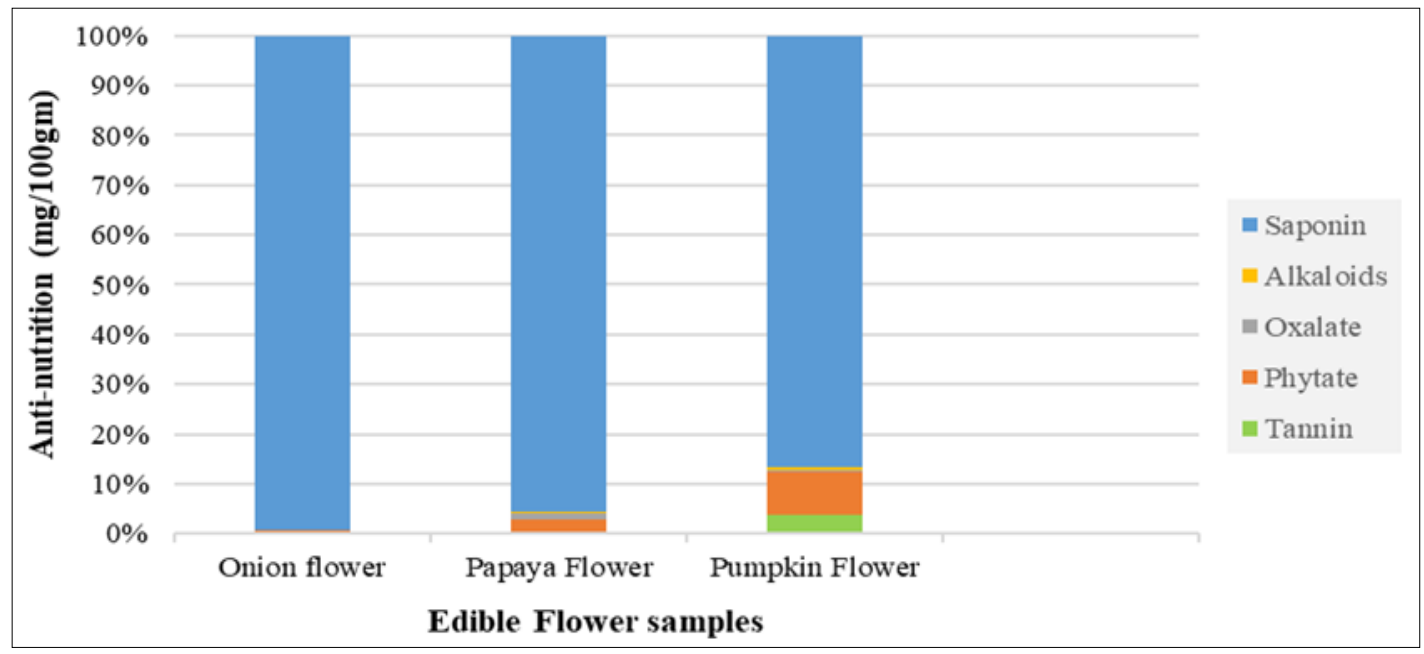

Fig 1: Graphical representation of the antinutritional determination

The antinutritional factor analysis has been carried out for each of the three edible flowers separately and the results obtained has been summarised in Table 1 and graphically presented in Figure 1. All the values were taken in triplicate $(n=3)$ and the final results presented in \pm Standard Error of Mean (SEM) with the unit as $\mathrm{mg} / 100 \mathrm{gm}$.

The tannin concentration was determined by the standard graph of tannic acid solution and it was found that amongst the three test flowers, Cucurbita maxima flowers $(2.16 \pm 0.17 \mathrm{mg} / 100 \mathrm{gm})$ have a slightly higher tannin concentration than Allium cepa umbel $(1.72 \pm 0.35 \mathrm{mg} / 100 \mathrm{gm})$ and Carica papaya flowers $(0.44 \pm 0.36 \mathrm{mg} / 100 \mathrm{gm})$. Carica Papaya umbel have a higher content of phytates $(6.58 \pm 0.05 \mathrm{mg} / 100 \mathrm{gm})$ compared to Cucurbita maxima
$(5.07 \pm 0.10 \mathrm{mg} / 100 \mathrm{gm})$

and

Allium

cepa $(3.06 \pm 0.03 \mathrm{mg} / 100 \mathrm{gm})$ flowers. Oxalate is highest in Carica Papaya flowers $(3.18 \pm 0.18 \mathrm{mg} / 100 \mathrm{gm})$ with Allium cepa umbel $(1.51 \pm 0.16 \mathrm{mg} / 100 \mathrm{gm})$ next in line followed by Cucurbita maxima flowers with very little oxalate content $(0.2 \pm 0.19 \mathrm{mg} / 100 \mathrm{gm})$. Alkaloids are found in very small amount in all the three sample flowers with Allium cepa having the highest $(0.88 \pm 0.43 \mathrm{mg} / 100 \mathrm{gm})$ and Carica papaya $(0.18 \pm 0.02 \mathrm{mg} / 100 \mathrm{gm})$ with the least. Cucurbita maxima flowers have $50 \pm 30 \mathrm{mg} / 10 \mathrm{gm}$ of saponin followed by Carica papaya flowers $(230 \pm 20 \mathrm{mg} / 100 \mathrm{gm})$ and Allium cepa umbel containing the majority $(850 \pm 10 \mathrm{mg} / 100 \mathrm{gm})$.

\subsection{Comparative Study 1}

Table 2: Anti-nutritional contents of Allium cepa, Carica papaya and Cucurbita maxima flowers compared to Carica papaya fruit ${ }^{[17,}$ ${ }^{19]} /$ Cucurbita maxima fruit ${ }^{[17,21,22]} /$ Allium cepa bulb ${ }^{[16,17,18]}$ and Carica papaya leaf ${ }^{[20]}$, Cucurbita maxima leaf ${ }^{[17,23] / A l l i u m}$ cepa stalk ${ }^{[17]}$

\begin{tabular}{|c|c|c|c|c|c|c|c|c|c|}
\hline Antinutritional & \multicolumn{3}{|c|}{ Allium cepa } & \multicolumn{3}{c|}{ Carica papaya } & \multicolumn{3}{c|}{ Cucurbita maxima } \\
\cline { 2 - 10 } Factors (mg/100g) & Flower & Bulb & Stalk & Flower & Fruit & Leaf & Flower & Fruit & Leaf \\
\hline Tannins & $1.72 \pm 0.35$ & $0.22 \pm 0.03$ & - & $0.44 \pm 0.3$ & 6.0 & $310.50 \pm 11.5$ & $2.16 \pm 0.17$ & $0.35 \pm 0.1$ & $180 \pm 4$ \\
\hline Phytates & $3.06 \pm 0.03$ & 8.28 & $61.02 \pm 2.5$ & $6.58 \pm 0.05$ & $22.08 \pm 1.80$ & - & $5.07 \pm 0.10$ & $19.72 \pm 1.8$ & $38.27 \pm 1.20$ \\
\hline Oxalates & $1.51 \pm 0.16$ & $11.11 \pm 2.04$ & $29.72 \pm 6.1$ & $3.18 \pm 0.18$ & $9.38 \pm 1.3$ & - & $0.2 \pm 0.19$ & $41.22 \pm 10.34$ & $13.61 \pm 1.91$ \\
\hline Alkaloids & $0.88 \pm 0.43$ & $4.82 \pm 0.02$ & - & $0.18 \pm 0.02$ & - & $1569.13 \pm 92$ & $0.35 \pm 0.55$ & 0.176 & $631 \pm 5$ \\
\hline Saponins & $850 \pm 10$ & $1110 \pm 100$ & $540 \pm 40$ & $230 \pm 20$ & $430 \pm 40$ & $898.07 \pm 20.6$ & $50 \pm 30$ & - & $69 \pm 1$ \\
\hline
\end{tabular}

Results presented are mean \pm SEM $(n=3)$ 


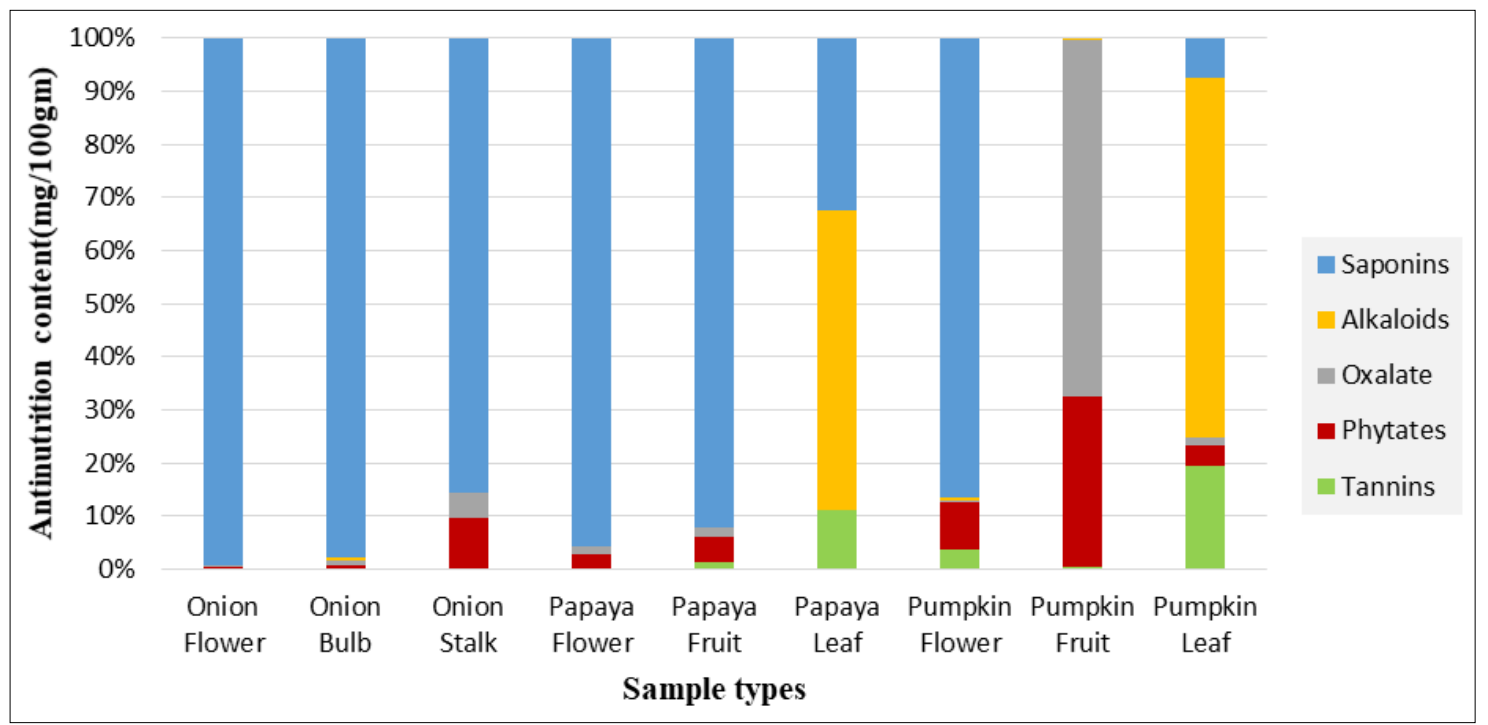

Fig 2: Anti-nutrition content from the edible flowers of Allium cepa, Carica papaya and Cucurbita maxima compared with its respective leaf/stalk and fruit/bulb

The anti-nutrient content of the three studied edible flowers have been compared to their respective fruit/bulb and leaf/stalk in Table 2 and pictorially represented in Figure 2.

The fresh edible flowers of Allium cepa have a tannin content of $1.72 \pm 0.35 \mathrm{mg} / 100 \mathrm{gm}$ which is slightly higher than the tannins recorded in White Allium cepa bulb $(0.22 \pm$ $0.003 \mathrm{mg} / 100 \mathrm{gm}){ }^{[13]}$. The Cucurbita maxima flowers have a tannin content of $2.16 \pm 0.17 \mathrm{mg} / 100 \mathrm{gm}$ which is higher than the tannin content of pumpkin pulp $(0.358 \pm 0.100$ $\mathrm{mg} / 100 \mathrm{gm}){ }^{[17]}$ but much lesser than the tannin content of raw edible pumpkin leaf $(180 \pm 4 \mathrm{mg} / 100 \mathrm{gm}){ }^{[19]}$. Carica papaya flowers have a tannin content of $0.44 \pm 0.36 \mathrm{mg} / 100 \mathrm{gm}$ which is lesser than the tannin concentration of raw papaya extracts $\left(6.0 \mathrm{mg} / 100 \mathrm{~g}\right.$ fresh weight ${ }^{[15]}$ and papaya leaf with a high tannin content $(310.50 \mathrm{mg} / 100 \mathrm{gm}){ }^{[16]}$. Tannins form reversible and irreversible tannin-protein complexes with protein, starch and metal chelates and inhibit the activities of some dietary enzymes such as trypsin, chymotrypsin, amylase and lipase and interfere with dietary iron absorption ${ }^{[20]}$.

As the daily intake of tannin below the range of 1.5-2.5 $\mathrm{g}$ is safe for human consumption and do not interfere with iron absorption from diet ${ }^{[21]}$, the edible flowers of Allium cepa, Cucurbita maxima and Carica papaya can be safely consumed without any potential side effects.

Human digestive systems are incapable of metabolizing phytate as it forms insoluble salts with essential minerals like calcium, iron, magnesium and zinc in food rendering them unavailable for absorption into the blood stream ${ }^{[22]}$. The edible Allium cepa umbel per $100 \mathrm{gm}$ contain $3.06 \pm 0.03 \mathrm{mg}$ of phytates which is much less compared to its stalk and bulb containing $61.02 \mathrm{mg} / 100 \mathrm{gm}{ }^{[14]}$ and $8.28 \mathrm{mg} / 100 \mathrm{gm}$ [14] respectively. Carica papaya umbel is found to have a lower amount of phytate content $(6.58 \pm 0.05 \mathrm{mg} / 100 \mathrm{gm})$ when compared to the raw papaya fruit having $22.08 \pm 1.80 \mathrm{mg} /$ $100 \mathrm{gm}{ }^{[14]}$. Also the Cucurbita maxima flowers have $5.07 \pm 0.10 \mathrm{mg} / 100 \mathrm{gm}$ of phytate when compared to its fruit and leaf containing much higher amounts $\left(19.72 \pm 1.8^{[14]}\right.$ and $38.27 \pm 1.20 \mathrm{mg} / 100 \mathrm{gm}^{[14]}$ respectively). Humanphytate intake can be as low as250-350 mg (Western diet) and can even go up to $(\geq 1000 \mathrm{mg})$. Thus the studied edible flowers are food sources within the safe limits of phytate intake ${ }^{[23]}$.

Oxalic acid can form soluble or insoluble salts or esters called oxalates like Calcium oxalate which may have a deleterious effect on human nutrition and health by accumulating kidney stones ${ }^{[24]}$. A diet containing less than $50 \mathrm{mg}$ of oxalate per day is recommended because the proportion of dietary oxalate absorbed increases more sharply in a low oxalate diet, thus reducing the risk of developing Calcium oxalate stones ${ }^{[25]}$.The edible flowers of Allium cepa $(1.51 \pm 0.16 \mathrm{mg} / 100 \mathrm{gm})$, Cucurbita maxima $(0.2 \pm 0.19 \mathrm{mg} / 100 \mathrm{gm})$ and Carica papaya $(3.18 \pm 0.18 \mathrm{mg} / 100 \mathrm{gm})$ have a much lesser amount of oxalate when compared to their respective onion bulb $(11.11 \pm 2.04 \mathrm{mg} / 100 \mathrm{gm}) \quad[14] /$ fruits of pumpkin $(41.22 \pm 10.34 \mathrm{mg} / 100 \mathrm{gm})^{[14]}$, papaya $(9.38 \pm 1.3 \mathrm{mg} / 100 \mathrm{gm})^{[14]}$ and onion stalk $(29.72 \pm 6.15 \mathrm{mg} / 100 \mathrm{gm})^{[14]} /$ pumpkin leaf $(13.61 \pm 1.91 \mathrm{mg} / 100 \mathrm{gm})^{[14]}$. As vegetable food sources the studied flowers are low in oxalate and can be consumed freely.

Alkaloids are considered to be anti-nutrients because of their action on the nervous system and inappropriate augmentation of electrochemical transmission. Alkaloids also cause gastrointestinal and neurological disorders [26]. Alkaloid content of the Allium cepa umbel $(0.88 \pm 0.43 \mathrm{mg} / 100 \mathrm{gm})$ is lesser than its bulb $(4.82 \pm 0.02 \mathrm{mg} / 100)^{[13]}$. The Carica papaya flowers contain about $0.18 \pm 0.02 \mathrm{mg} / 100 \mathrm{gm}$ which is almost negligible when compared to its leaf (1569.13 \pm $92.58 \mathrm{mg} / 100 \mathrm{gm}){ }^{[16]}$ being extremely rich in alkaloid. The Cucurbita maxima flowers $(0.35 \pm 0.55 \mathrm{mg} / 100 \mathrm{gm})$ are slightly higher in alkaloid content when compared to its fruit pulp $(0.176 \mathrm{mg} / 100 \mathrm{gm}){ }^{[18]}$ but the leaves $(631 \pm 5 \mathrm{mg} / 100 \mathrm{gm}){ }^{[19]}$ are rich in alkaloid. Thus the flowers are very low in oxalate content and do not pose any risk of alkaloid toxicity.

Saponins have been historically considered as antinutritional factors due to its adverse effects on growth impairment, reduced food intake, bitterness and throat-irritating activity but contemporary researches have indicated that some saponins stereoisomers may show stereospecific pharmacological activities, as well as stereoselective effects on ion channel current regulation, cardiovascular system, and immune system. Safe intakes may vary from about 9 to 420 $\mathrm{mg} /$ day for saponins ${ }^{[27]}$. The flowers of Allium cepa, Carica papaya and Cucurbita maxima have a relatively high level of saponin containing $850 \pm 10 \mathrm{mg} / 100 \mathrm{gm}, 230 \pm 20 \mathrm{mg} / 100 \mathrm{gm}$ and $50 \pm 30 \mathrm{mg} / 100 \mathrm{gm}$ respectively when compared to the other measured anti-nutrient contents of the flowers. The edible flower's saponin concentration is lower than their fruit or leafy counterparts as presented in Table2. 


\subsection{Comparative Study 2}

Table 3: Anti-nutritional contents of Allium cepa, Carica papaya and Cucurbita maxima flowers compared to other common edible flowers

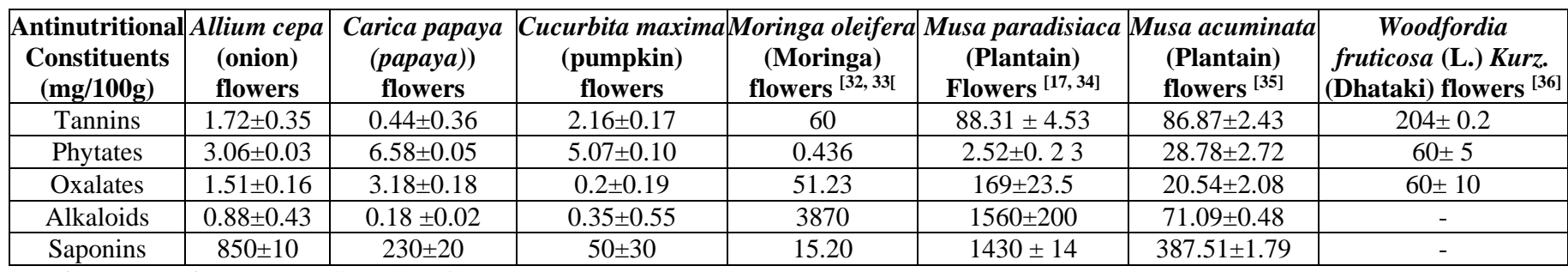

Results presented are mean \pm SEM $(n=3)$

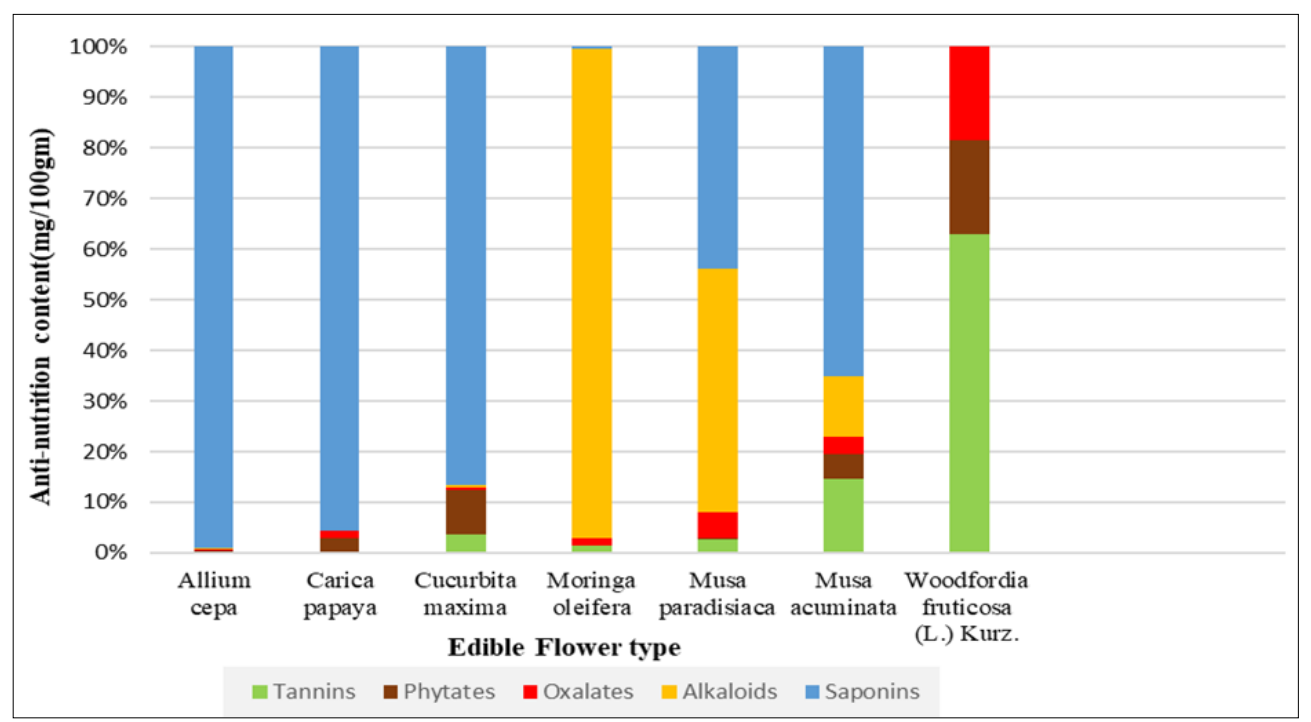

Fig 3: Graphical representation of the Anti-nutritional contents of Allium cepa, Carica papaya and Cucurbita maxima flowers compared to other common edible flowers

In Table 3, Allium cepa, Carica papaya and Cucurbita maxima flowers have been compared with four other commonly consumed edible flowers, namely Moringa oleifera, Musa paradisiaca, Musa acuminata and Woodfordia fruticosa (L.) Kurz. The four edible flowers have been chosen because of their easy availability and high consumption rate across wide range of areas in South East Asian countries. The literature on phytochemical studies shows that the flowers of Moringa oleifera, Musa paradisiaca, Musa acuminata and Woodfordia fruticosa (L.) Kurz have higher amount of antinutritional content when compared to the edible flowers of Allium cepa, Carica papaya and Cucurbita maxima.

Amongst the compared flowers, Carica papaya have the least number of tannins $(0.44 \pm 0.36 \mathrm{mg} / 100 \mathrm{gm})$ with Woodfordia fruticosa (L.) Kurz. Having the highest amount (204 \pm $0.2 \mathrm{mg} / 100 \mathrm{gm}){ }^{[32]}$. Though the entire plant parts of Woodfordia fruticosa Kurz is consumed in different South East Asian countries because of its many therapeutic properties, but particularly, its flowers are in great demand in domestic and international markets specialized in the preparation of herbal medicines.

Moringa oleifera flowers have the least amount of phytates $(0.436 \mathrm{mg} / 100 \mathrm{gm}){ }^{[28]}$ while the Woodfordia fruticosa $(\mathrm{L}$. Kurz flowers have the most $(60 \pm 5 \mathrm{mg} / 100 \mathrm{gm}){ }^{[32]}$ amongst the compared flowers.

Cucurbita maxima flowers have the least amount of oxalate having $0.2 \pm 0.19 \mathrm{mg} / 100 \mathrm{gm}$ and Musa paradisiaca flowers have the highest quantity having $169 \pm 23.5 \mathrm{mg} / 100 \mathrm{gm}$ [14] amongst the compared edible flowers. The flowers of Musa paradisiacaare used to treat ulcers, dysentery, and bronchitis and cooked flowers are good food for diabetics, cooked as vegetable in South-East Asia ${ }^{[33]}$.

Carica papaya having $0.18 \pm 0.02 \mathrm{mg} / 100 \mathrm{gm}$ carries the lowest amount of alkaloid, with Moringa oleifera flowers containing an enormous amountof $3870 \mathrm{mg} / 100 \mathrm{gm}{ }^{[29]}$. The moringa flowers have been traditionally used in tonics that are meant to reduce inflammation and for nursing mothers. The flowers are also enjoyed as a snack by deep frying them in oil [34].

The saponin content of all the three test flowers is relatively high. But when compared to the other four edible flowers, it is found that the Moringa oleifera flowers have the smallest amount $(15.20 \mathrm{mg} / 100 \mathrm{gm})^{[28]}$ while the Musa paradisiaca flowers have the highest $(1430 \pm 14 \mathrm{mg} / 100 \mathrm{gm})^{[30]}$. This confirms that the studied edible flowers of Allium cepa, Carica papaya and Cucurbita maxima are relatively low in anti-nutritional content than some of the most common edible flowers available.

\section{Conclusion}

Antinutrients are chemicals which have been evolved by plants for their own defence and reduces the maximum nutritive value present in a food. Some of these plant chemicals are either harmful to health or evidently advantageous to human and animal health if consumed at appropriate amounts ${ }^{[35]}$.

The studied flowers of Allium cepa, Carica papaya and Cucurbita maxima are low in anti-nutrients (tannin, phytate, oxalates, alkaloids) but the saponin content is significantly higher in the three flowers. Although saponins were recognized as anti-nutrient constituents, studies suggests that saponins possess hypocholesterolaemia, immunostimulatory 
and anticarcinogenic properties [36]. Tannins, water-soluble polyphenol have a great role in reforming the mood, increasing alertness as well as performance of an individual, if used within the permissible limits ${ }^{[37]}$. The flowers of Allium cepa, Carica papaya and Cucurbita maxima have tannin in very small amounts when compared to a single cup of tea containing approximately $195 \mathrm{mg} / 100 \mathrm{~g}$ of tannins ${ }^{[15]}$.

Most of the toxic and antinutrient effects in the flowers could be removed by several processing methods. Although the processing treatments may alter the chemical composition and mineral content of the flowers to some extent, but the use of certain traditional food preparation methods such as fermentation, cooking, soaking and puffing can significantly reduce the anti-nutrient content. Pressure cooking was found to be the best process for removal of anti-nutritional factors [38]. Thus the studied edibles flowers being poor sources of antinutrient content, makes the flowers much favourable for consumption.

\section{Acknowledgment}

The authors of this study are thankful to University Grants Commission (UGC), India for providing the necessary funding for carrying out this research work.

\section{References}

1. Aneta Popova, Dasha Mihaylova. Antinutrients in Plantbased Foods: A Review. The open Biotechnology Journal 2019;13:68-76.

2. Petroski W, Minich DM. Is There Such a Thing as "AntiNutrients"? A Narrative Review of Perceived Problematic Plant Compounds. Nutrients 2020;12(10):2929.

3. Inuwa Hajia Mairo, Aina VO, Baba Gabi, Idowu Aimola, Toyin A. Comparative Determination of Antinutritional Factors in Groundnut Oil and Palm Oil. Advance, 2011;3(4):275-279.

4. Nath KVS, Rao Knv, David Banji, Sandhya SA. Comprehensive review on Allium cepa. Journal of Advanced Pharmaceutical Technology \& Research. 2010;1:94-100.

5. King Bergonio B, Milagros Perez A. The potential of male papaya (Carica papaya, L.) flower as a functional ingredient for herbal tea production. Indian journal of Traditional knowledge 2016;15:41-49.

6. Luigi de, Bellis Ryuji, Tsugeki Mikio, Nishimura. Glyoxylate Cycle Enzymes in Peroxisomes Isolated from Petals of Pumpkin during Senescence. Plant and Cell Physiology. 1991;32:1227-1235.

7. Mohammad Zakir, Masayuki Fujita. Purification of a Phitype Glutathione $S$-Transferase from Pumpkin Flowers and Molecular Cloning of Its cDNA. Bioscience, Biotechnology and Biochemistry. 2014;6:2068-2076.

8. Vasundhara Saxena, Chagti KK. The effect of climate on total phenolics in Macrotyloma uniflorum, Vigna unguiculata, Cinnamomum zeylanicum and Mentha piperita using spectrophotometer. Asian Journal of Pharmaceutical and Clinical Research. 2016;9(5):59-61.

9. Lucas GM, Markakas. Phytic acid and other phosphorus compounds of bean (Phaseolus vulgaris). J Agric. Edu. Chem. 1975;23:13-15.

10. Chinma CE, Igyor MA. Micronutrients and antinutritional contents of selected tropical vegetables grown in Southeast, Nigeria. Nigerian Food Journal. 2007;25:111-116.

11. Rastogi RP, Mehrotra BN. Compendium of Indian
Medicinal Plants: Lucknow and Publications \& Information Directorate New Delhi, 1993.

12. Obadoni BO, Ochuko PO. Phytochemical studies and comparative efficacy of the extracts of some haemostatic plants in Edo and Delta States of Nigeria. Glob J Pure Appl Sci. 2001;8:203-208.

13. Akin-Osanaiye, Bukola Catherine, Godwin Gabriel. Antibacterial Activity and Anti-nutrient Composition of White and RED Allum cepa (Onion). Direct Research Journal of Public Health and Environmental Technology. 2018;3:41-47.

14. Gopalan C, Rama Sastri BV. Indian Food Composition Tables, Nutritive Value of Indian Foods (NVIF): National Institute of Nutrition (Indian Council of Medical Research), 2017.

15. Annegowda HV, Rajeev Bhat, Kar Joon Yeong, Min-Tze Liong, Karim AA, et al. Influence of Drying Treatments on Polyphenolic Contents and Antioxidant Properties of Raw and Ripe Papaya (Carica papaya L.). International Journal of Food Properties 2014;17:283-292.

16. Nwamarah Joy Ugo, Adesanmi Raymond Ade, Asogwa Tochi Joy. Nutrient Composition of Carica papaya Leaves Extracts. J Food Sci Nutr Res. 2019;2:274-282.

17. Adebayo O. R, Farombi A. G, Oyekanmi A.M. Proximate, Mineral and Anti-Nutrient Evaluation of Pumpkin Pulp (Cucurbita Pepo). IOSR Journal of Applied Chemistry (IOSR-JAC) 2013;4:25-28.

18. Ghosh P., Rana S.S. Physicochemical, nutritional, bioactive compounds and fatty acid profiling of Pumpkin flower (Cucurbita maxima), as a potential functional food. SN Appl. Sci. 2021;3:216.

19. Yusufu M I, Obiegbuna J E. Effect of processing methods on the phytochemical content and consumer acceptability of two selected green leafy vegetables. Agricultural Science Research Journal. 2015;5:105-110.

20. Rao P, Desothale YG. Tannin content of pulses varietal difference and effects of germination and cooking. J. Sci. food Agric. 1998;33:1013-1015.

21. Rao BS, Prabhavathi T. Tannin content of foods commonly consumed in India and its influence on ionisable iron. Journal of the Science of Food and Agriculture. 1982;33:89-96.

22. Bingham S. Health effects, sources, utilization and safety of tannins: a critical review. Nutritional A Consumer Guide to Good Eating, Trans World Publishers London, 1978, 26-50.

23. Lisbeth Bohn, Anne Meyer S, Søren Rasmussen K. Phytate: impact on environment and human nutrition. A challenge for molecular breeding. J Zhejiang Univ Sci B. 2008;9(3):165-191.

24. Olawoye BT, Gbadamosi SO. Effect of different treatments on in vitro protein digestibility, antinutrients, antioxidant properties and mineral composition of Amaranthus viridis seed. Cogent Food \& Agriculture 2017;3:1.

25. Holmes RP, Goodman HO, Assimos DG. Contribution of dietary oxalate to urinary oxalate excretion. Kidney Int. 2001;59(1):270-6.

26. Aletor VA. Allelochemicals in plant foods and feeding Stuffs. Part I. Nutritional, and Physio pathological aspects in animal production. Vet. Human Toxicol. 1993;35(1):57-67.

27. John Shi, Konesh Arunasalam, David Yeung, YukioKakuda, Gauri Mittal, Yueming Jian. Saponins from Edible Legumes: Chemistry, Processing, and Health 
Benefits. J Med Food. 2004;7(1):67-78.

28. Igwilo IO, Ezeonu FC, Udedi SC, Ubaoji KI, Ozumba NA, Ogbunuga HA. Nutrient composition and antinutritional factors in a local cultivar of Moringa oleifera (Lam) flowers. Natural Products: An Indian Journal NPAIJ. 2011;7(2):86-90.

29. Kshirsagar RB, Sawate AR, Patil BM, Zaker MA. Studies on nutritional profile of different parts of Moringa oleifera (Leaf, flower and pod). Food Sci. Res. J. 2017;8(1):21-24.

30. Lavanya K, Abi Beaulah G, Vani G. Musa paradisiacaa review on phytochemistry and pharmacology. World journal of pharmaceutical and medical research. 2016;2(6):163-173.

31. Ramith Ramu, Prithvi Shirahatti S, Anilakumar KR, Shivasharanappa Nayakavadi, Farhan Zameer BL. Dhananjaya MN, et al. Assessment of Nutritional Quality and Global Antioxidant Response of Banana (Musa sp. CV. Nanjangud Rasa Bale) Pseudostem and Flower. Pharmacognosy Res. 2017;9(1):74-83.

32. Shivprasad Mahadkar, Sujata Valvi, Varsha Rathod. Screening of anti-nutritional factors from some wild edible plants. J Nat. Prod. Plant Resour. 2012;2(2):251255.

33. Shruthi D. Medicinal uses of banana (Musa paradisiaca). Drug Invention Today. 2019;12(1).

34. Ritu Paliwal, Veena Sharma, Pracheta. A Review on Horse Radish Tree (Moringa oleifera): A Multipurpose Tree with High Economic and Commercial Importance. Asian Journal of Biotechnology. 2011;3:317-328.

35. Habtamu Fekadu Gemede. Antinutritional Factors in Plant Foods: Potential Health Benefits and Adverse Effects. International Journal of Nutrition and Food Sciences. 2014;3(4):284.

36. Oleszek WA. Chromatographic determination of plant saponins. J Chromatogr. A. 2002;967:147-162.

37. Morton JF. Widespread tannin intake via stimulants and masticatories, especially guarana, kola nut, betel vine, and accessories in Plant Polyphenols. Boston, MA: Springer, 1992, 739-765.

38. Handa V, Kumar V, Panghal A, Suri S, Kaur J. Effect of soaking and germination on physicochemical and functional attributes of horse gram flour. Journal of Food Science and Technology. 2017;54(13):4229-4239. 